\title{
How the Universities of technology cooperates with SMEs on the example of Polish universities
}

\author{
JUSTYNA BĘTLEWSKA \\ Institute of management \\ Warsaw School of Economics \\ al. Niepodległości 162, 02-554 Warsaw \\ POLAND
}

\begin{abstract}
The fundamental aim of the study is to indicate how Polish universities of technology cooperate with enterprises belonging to the small and medium-sized enterprise sector. The study was conducted from the perspective of polytechnic schools. Given the goal indicated in this way, the key activities included obtaining an answer to the question regarding the scope, conditions, and quality of cooperation between small and mediumsized enterprises and technical universities. In-depth literature studies in the indicated research problem, own observations as well as conducting empirical research contributed to the formulation of detailed questions, the solution of which determined the answer to the main problem, which is to indicate how Polish technical universities cooperate with small and medium-sized enterprises on the example of Polish technical universities. The conducted research allowed to obtain an answer to the question concerning the motivating and limiting factors, including the cooperation of technical universities with small and medium-sized enterprises. This publication, constituting an empirical cognitive foundation, can be a starting point for further considerations on the increase in the importance and role of cooperation, as well as a better understanding of new challenges in the development of the modern economy. The paper focuses on showing the phenomenon of cooperation, systematizing this phenomenon in the theory of management, and also on presenting the results of own research along with the methods of its implementation. This paper is important to better understand the importance of collaboration between science and business and create new opportunities to develop areas of collaboration.
\end{abstract}

Keywords: cooperation, small and medium-sized enterprises, polytechnics, economy, polytechnic, polish university.

Received: April 29, 2021. Revised: November 9, 2021. Accepted: December 16, 2021. Published: January 11, 2022.

\section{Introduction}

The phenomenon of cooperation is of particular importance nowadays. The role and significance of searching for new solutions as well as areas of cooperation are more and more visible, which is particularly related to the emergence of new challenges that currently face technical universities in the context of cooperation with other units. The aspect becomes more and more visible.

\footnotetext{
${ }^{1}$ Sandberg, S. (2012). Internationalization processes of small and medium- sized enterprises: Entering and taking off from emerging markets (Doctoral Dissertation). Retrieved from http://www.divaportal.org/smash/record.jsf?pid=diva2\%3A504939\&dsw $\mathrm{id}=-2578$.
}

The internationalization of enterprises has become an extremely important research area in recent years ${ }^{1}$. On the other hand, the still systematically progressing globalization has made the activity of companies with an international scope even more important for the search for opportunities and opportunities to cooperate with other entities, such as technical universities, to introduce innovative projects into the economy ${ }^{2}$. The development of small and medium-sized enterprises is a priority

\footnotetext{
2 Susanne Mueller-Using, Wieslaw Urban, Jan Wedemeier (2020) Internationalization of SMEs in the Baltic Sea

Region: Barriers of cross-national collaboration considering regional innovation strategies for smart specialization, Wiley Periodicals LLC, p.2.
} 
action for the governments of many countries, therefore their distinguishing position on the market is extremely important for cooperation with other research and development units, which include technical universities ${ }^{3}$.

The broadly understood cooperation between technical universities and small and mediumsized enterprises is extremely important and constitutes an extremely interesting research area. The analysis of the literature on the subject and statistical data to date indicates not only the lack of identification of the condition of such cooperation, but also the determinants and factors limiting cooperation between enterprises and technical universities, such as polytechnic universities. The CATI method was used to solve the resulting research problem, and the interviews conducted using this method were valuable information for determining particularly important aspects related to cooperation between science and business.

\section{Cooperation in the theory of management and quality sciences - systematizing considerations}

Nowadays, it can be seen that the measure of the development of enterprises is their ability and ability to cooperate. In turn, technical universities also need such a partner to share their own research results or knowledge. The literature on the subject indicates a number of definitions of the concept of cooperation. In the era of increasingly growing turbulences in the economy, the aspect of cooperation becomes more and more important. By and large, the idea

https://onlinelibrary.wiley.com/doi/epdf/10.1111/grow.1 2439

${ }^{3}$ Hazem ALI, Yunhong HAO, Chen AIJUAN, (2020)

Innovation Capabilities and Small and Medium

Enterprises' Performance: An Exploratory Study, The

Journal of Asian Finance, Economics and Business

Vol.7 No.10 pp. 959 DOI :

https://doi.org/10.13106/jafeb.2020.vol7.no10.959, ISSN 2288-4645, pp. 2288-4645.

4 N.R. dos Santos a,b, C. Figueiredoc, d, L. Pais e,f, (2020) Development and validation of the organisational cooperation questionnaire, European Review of Applied Psychology Volume 70, Issue 4, October 2020, 100555, p.1. of cooperation between technical universities and SMEs incorporates all the efficient exercises. The objective of such helpful relations between the technical universities and the SMEs is to get to innovations, the advancement of eliminating outskirt information, the development of monetary assets, and the utilization of the inventive capacities of universities. Cooperation is the basic framework for the functioning of the economy and society ${ }^{4}$. In turn, enterprises react openly, adapting their innovation and research development strategies. Cooperation with research and development units, which include technical universities, this type of unit is an extremely important entity for creating added value in the enterprise ${ }^{5}$.

There are many definitions of the concept of cooperation in the literature on the subject. For M. Grabowska, cooperation is understood as the division of resources or information in order to achieve the desired, common or individual results of cooperating partners ${ }^{6}$. However, the most common definition is that of collaboration as the links between organizations that pursue mutually consistent goals to achieve in relation to these benefits. This means creating links on various levels with varying degrees of persistence and intensity ${ }^{7}$. The relationship can take various forms, ranging from long-term and broad cooperation to narrow and one-time. Given this approach, enterprises and universities that undertake cooperation assume the role of an accelerator in the process of innovation development ${ }^{8}$. Continuing this discussion, it should be emphasized that more of this cooperation is created on a larger scale and

\footnotetext{
${ }^{5}$ Meissner D. (2015) Public-Private Partnership Models for Science, Technology, and Innovation Cooperation, Springer, s.1.

6 Grabowska M., Współdziałanie przedsiębiorstw w perspektywie sieciowej, „Organizacja i Zarządzanie. Zeszyty Naukowe Politechniki Śląskiej”, nr.76, 2014, s. 51-61.

7 Adamik A., Powiązania wspótpracy międzyorganizacyjnej $w$ zarządzaniu współczesnymi przedsiębiorstwami [w:] W. Kowalczewski, W. Matwiejczuk, (red.) Zarządzanie organizacjami w teorii i praktyce, Difin, Warszawa 2008, s. 60-73.

8 Roper S. Love J.H, Knowledge context, learning and innovation: an integrating framework, "Industry and Innovation", vol. 25(4), 2018, s. 339-364.
} 
begins to cover a wider scope, the more opportunities it provides for the development, reducing barriers and limitations to cooperation 9 . Shaping the appropriate economic, social, cultural, and institutional conditions will be a factor triggering entrepreneurship and favor the cooperation of enterprises, in particular small and medium-sized enterprises in the field of technology.

The links that exist between the world of science and have a multifaceted nature, carrying out its activities in various relationships in which there is a mutual exchange of information, knowledge ,or other, other resources. The basic types of relations between science and business include 10.

- Research partnerships;

- Research services;

- Academic entrepreneurship;

- Mobility of human capital;

- Informal networks of contacts;

- Joint scientific publications

- Transfer of intellectual rights (patenting, licensing)

The benefits that are obtained from cooperation are mutual, although in this study attention will be paid to the search for an answer to the question of what such cooperation looks like by showing the motives of cooperation, limiting factors, and the most important aspects.

\section{Material and method}

The aim of the study was to indicate by technical universities - Polytechnics in Poland, what is the condition of cooperation between universities and small and medium-sized enterprises. 5 polytechnics were invited to the study, thus constituting over $30 \%$ of all polytechnic universities in Poland. The survey was conducted in the form of a telephone interview with experts / brokers of cooperation between the universities and small and medium-sized

9 Micek G., Piziak B., Wpływ bliskości międzyorganizacyjnej na rozwój usług IT w Krakowie i na Górnym Śląsku, "Studia Ekonomiczne. Zeszyty Naukowe Uniwersytetu Ekonomicznego w Katowicach", nr 320, 2017 s. 107-128. enterprises. The experts in the study were employees of the Technology Transfer Center at the studied universities, and their selection for the study depended on their experience and work experience at the Technology Transfer Center. The telephone interview, during which 10 open questions were asked, concerned cooperation between universities of technology and enterprises from the point of view of technical universities. A request was made about the motives for cooperation and the barriers which they have to overcome to establish cooperation.

The study, whose findings are discussed in this paper, was conducted in the second quarter of 2019 in random purposive sampling. The study identified characteristics of the group of respondents. NVivo was used to analyze the qualitative interviews. Due to the size of the sample, the results obtained during the empirical study cannot be generalized for the entire population of the University of Technology.

The following universities took part in the study:

1. Warsaw University of Technology

2. Gdańsk University of Technology

3. Poznań University of Technology

4. Lublin University of Technology

5. Rzeszów University of Technology

The interview was one-off. The interviewees technology transfer brokers did not know the questions before. The answer were spontaneous and honest. The selection of experts/brokers as well as universities of technology was random. The study covered collaborative activities over a period of 5 years, i.e., from 2014 to 2019.

\section{Research results}

Technical universities have separate units, i.e. Technology Transfer Center, whose task is to look for opportunities to start cooperation with

10 A. Marszałek, Relacje między światem nauki i przemysłu, „e-mentor” 2014, nr 56(4), s. 44-53, https://doi. org/10.15219/em56.1123. 
other entities, including small and mediumsized enterprises. This cooperation is most commonly undertaken with industries closely corresponding to their faculties at the university. During the survey, representatives of technical universities were asked about the motives for cooperation. In their opinion, there is an impact of establishing cooperation between small and medium-sized enterprises and technical universities. This enables the identification of motives and factors limiting the establishment of cooperation. The indicated motives and limitations of cooperation are included in Table 1.

Table 1. Motives and barriers in cooperation between polytechnic universities and small and medium-sized enterprises.

\begin{tabular}{|c|c|c|}
\hline $\begin{array}{l}\text { University } \\
\text { name }\end{array}$ & $\begin{array}{l}\text { Factors } \\
\text { motivating to } \\
\text { cooperation }\end{array}$ & $\begin{array}{l}\text { Factors limiting } \\
\text { cooperation }\end{array}$ \\
\hline $\begin{array}{l}\text { Gdańsk } \\
\text { University } \\
\text { of } \\
\text { Technology }\end{array}$ & $\begin{array}{l}\text { - Having a } \\
\text { very large } \\
\text { base of a team } \\
\text { of scientists } \\
\text { with } \\
\text { extensive } \\
\text { scientific and } \\
\text { expert } \\
\text { experience; } \\
\text { - equipment } \\
\text { and } \\
\text { laboratories; } \\
\text { - location, } \\
\text { rich history, } \\
\text { knowledge of } \\
\text { universities } \\
\text { throughout } \\
\text { Pomerania; } \\
\text { - willingness } \\
\text { to find the } \\
\text { best solution } \\
\text { for a given } \\
\text { problem; }\end{array}$ & $\begin{array}{l}\text { - generating too } \\
\text { high costs caused } \\
\text { by introducing } \\
\text { changes in the } \\
\text { enterprise, which } \\
\text { limits the } \\
\text { willingness of } \\
\text { enterprises to } \\
\text { cooperate with the } \\
\text { university; }\end{array}$ \\
\hline $\begin{array}{l}\text { Lublin } \\
\text { University } \\
\text { of } \\
\text { Technology }\end{array}$ & $\begin{array}{l}\text { taking up a } \\
\text { new, } \\
\text { interesting } \\
\text { topic with an } \\
\text { entrepreneur, } \\
\text { which results } \\
\text { in scientific } \\
\text { cooperation; }\end{array}$ & $\begin{array}{l}\text { - lack of } \\
\text { understanding of } \\
\text { the time limit of a } \\
\text { scientist who } \\
\text { divides time into } \\
\text { teaching at the } \\
\text { university and } \\
\text { research activities; }\end{array}$ \\
\hline
\end{tabular}

\begin{tabular}{|c|c|c|}
\hline & $\begin{array}{l}\text { - increasing } \\
\text { the practical } \\
\text { dimension for } \\
\text { science; } \\
\text { - to be a better } \\
\text { and more } \\
\text { practical } \\
\text { educator; } \\
\text {-possibility to } \\
\text { obtain } \\
\text { additional } \\
\text { funds for } \\
\text { further } \\
\text { activities. }\end{array}$ & $\begin{array}{l}\text { - } \\
\text { misunderstandings } \\
\text { due to lack of time, } \\
\text { the scientist needs } \\
\text { additional time to } \\
\text { plan, carry out and } \\
\text { re-verify the } \\
\text { experiment. } \\
-\quad \\
\text { misunderstandings } \\
\text { resulting from } \\
\text { attempts to } \\
\text { circumvent formal } \\
\text { procedures (pay- } \\
\text { to-pocket by } \\
\text { enterprises). by }\end{array}$ \\
\hline $\begin{array}{l}\text { Warsaw } \\
\text { University } \\
\text { of } \\
\text { Technology }\end{array}$ & $\begin{array}{l}\text { - willingness } \\
\text { to execute } \\
\text { orders } \\
\text { reflecting the } \\
\text { market } \\
\text { reality; } \\
\text { - encountering } \\
\text { a real } \\
\text { problem } \\
\text { awaiting a } \\
\text { specific } \\
\text { technological, } \\
\text { scientific and } \\
\text { research } \\
\text { thought; }\end{array}$ & $\begin{array}{l}\text { carrying out many } \\
\text { research projects } \\
\text { at the same time; } \\
\text { - high time- } \\
\text { consuming } \\
\text { operation; } \\
\text { - different way of } \\
\text { thinking - scientist } \\
\text { versus } \\
\text { entrepreneur. }\end{array}$ \\
\hline $\begin{array}{l}\text { Poznan } \\
\text { University } \\
\text { of } \\
\text { Technology }\end{array}$ & $\begin{array}{l}\text { - enabling the } \\
\text { creation of a } \\
\text { new product, } \\
\text { technology; } \\
\text { - increasing } \\
\text { the chances of } \\
\text { receiving a } \\
\text { grant by } \\
\text { applying } \\
\text { jointly; }\end{array}$ & $\begin{array}{l}\text { the inability of } \\
\text { enterprises to } \\
\text { estimate the offer } \\
\text { whether it is } \\
\text { market or } \\
\text { overestimated; } \\
\text { - offering too low } \\
\text { remuneration for } \\
\text { developing new } \\
\text { technologies; } \\
\text {-no time to carry } \\
\text { out orders from } \\
\text { industry, in the } \\
\text { case of parallel } \\
\text { implementation of } \\
\text { own research } \\
\text { projects in order to } \\
\text { continue the } \\
\text { development of } \\
\text { one's own career. }\end{array}$ \\
\hline
\end{tabular}




\begin{tabular}{|c|c|c|}
\hline $\begin{array}{l}\text { Rzeszow } \\
\text { University } \\
\text { of } \\
\text { Technology }\end{array}$ & $\begin{array}{l}\text { - owned } \\
\text { human } \\
\text { resources; } \\
\text { - new } \\
\text { technologies; } \\
\text { - enabling the } \\
\text { product to be } \\
\text { tested when } \\
\text { the company } \\
\text { is unable to } \\
\text { do so; }\end{array}$ & $\begin{array}{l}\text { - too much } \\
\text { bureaucracy; } \\
\text { - formal barriers; } \\
\text { - fear of } \\
\text { entrepreneurs } \\
\text { starting } \\
\text { cooperation. }\end{array}$ \\
\hline
\end{tabular}

Source: Own study based on research.

Technical universities have many advantages thanks to which they can create opportunities for cooperation. Despite this, there are still a number of limitations that significantly prevent or act as a deterrent to cooperation. These factors, especially those contributing to the limitation of starting cooperation, may be valuable information for both universities and for entrepreneurs to further work on limiting such negative aspects of cooperation. Many of the above-mentioned barriers can be reduced or eliminated. The analysis of Table 1 also indicates that each of the cities indicates different motives and barriers related to the establishment of cooperation. This also implies that other factors depend on geographic location and experience of establishing cooperation.

The technical universities surveyed most often establish cooperation with production companies. Cooperation with enterprises is most often in line with the expectations of both parties. With their actions, the universities make every effort to ensure that the cooperation, as well as the relations achieved during the cooperation, are positive and partner-like. It is extremely important because this cooperation often translates into subsequent orders for additional research and searching for new solutions. This is confirmed by cases in which subsequent joint actions resulted in the purchase of a patent or improvement of a given product, thus increasing their efficiency.

In the years 2014-2019, a five-fold increase in interest in obtaining funds from the European Union was observed in all polytechnic universities surveyed. This cooperation in all polytechnic universities was formalized, although sometimes there were proposals to

circumvent the formal rules and conditions. These universities do not sign contracts that do not secure the interests of the university financially. The cooperation also usually proceeded as expected by both sides. The universities of technology strive to satisfy both sides. It is rare to break cooperation or not achieve the intended common goal. To better understand the issues of cooperation between both environments, the most important aspects of cooperation between universities and enterprises can be distinguished.

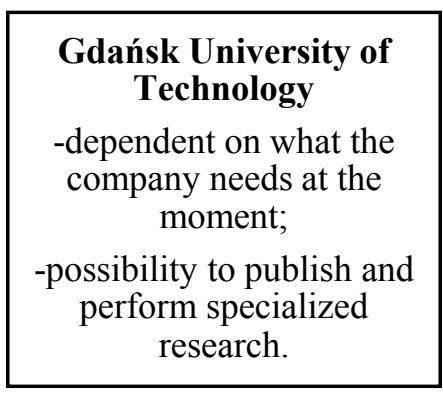

\section{Warsaw University of Technology}

- solving a specific problem at the scientific level; - the project contributes to the competences and scientific achievements of scientists.

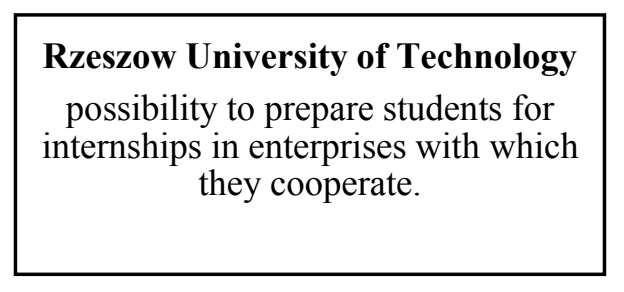

Fig. 1. The most important aspects of cooperation between universities and small and medium-sized enterprises.

Among the most important aspects of cooperation between universities and small and medium-sized enterprises, the impact of cooperation on the development of the entire economy is distinguished, so that the solutions created are implemented and best used in the economy. What is emphasized by all polytechnic universities surveyed in the 
selection of the right team for the project is extremely important. Not only because of the number of people in the team, there are 2-3 dedicated people for a given project, but above all, they fit into the competencies and scientific achievements of scientists. In the polytechnic universities studied, the aspect of enabling the preparation of students for internships in companies with which they cooperate is also important.

Polytechnics undertake a number of activities to establish cooperation with enterprises. Some of these activities are shown in Figure 2.

\section{organizing a conference}

$$
\text { trips to trade fairs }
$$

organizing meetings with entrepreneurs

participation in associations, clusters, running an innovation center

\section{creating a networking space}

Fig. 2. Actions taken by universities to establish cooperation

Technical universities meet the expectations of small and medium-sized enterprises and create many conditions for learning about mutual expectations and cooperation opportunities. Apart from the indicated trips to trade fairs, universities themselves create opportunities for meetings with entrepreneurs, including individual meetings. It is common practice to call companies to find out about their expectations and needs. In addition, various events are organized at the university, such as the open-door day at the university, dedicated to entrepreneurs - innovation open day, the idea of which is to create opportunities and opportunities for enterprises to learn about solutions that have recently been developed at the university and are presented to entrepreneurs. Additionally, activities are carried out in the media and on the university's internet forum to provide information about interesting solutions developed at universities. Through media drifting or individual meetings with journalists allowing talking and preparing material for the media. Additionally, cooperation with enterprises acting as intermediaries in searching for and combining business with science is undertaken.

According to the researched technical universities, their cooperation with enterprises increases the innovativeness of these enterprises. For the Gdańsk University of Technology, this cooperation has an impact thanks to the possibility of implementing new products and technological processes that enable them to develop. In the case of the Lublin University of Technology, such cooperation is one of the determinants. It is important to what extent enterprises are actually interested in increasing the level of their innovativeness and to what extent they are only interested in copying what is already on the market. If ithe company wants to be innovative, it must be aware of the fact of all kinds of such activities, for example, the effect of uncertainty, and be determined to actually talk about innovative solutions that will be ahead of market trends by looking for what will be needed soon and not what currently exists on the market. Additionally, financial stability is important as such activities cost money which can be a limiting factor. For the Warsaw University of Technology, product or technological innovation is important at the time when these measures are taken under EU funding ends at the stage of implementing a new product. The sale of licenses or patents is also intended to increase the innovativeness of enterprises. As a result, everything that the University of Technology does is to have a measurable benefit, such that the entrepreneur invests his funds to make it better and stand out from the competition. To make the technology more effective, economical, which will increase the team. The Poznan University of Technology also confirms this assumption, which then translates into the implementation of the results 
of cooperation scored in the parametric evaluation of the faculties of the Poznan University of Technology. The Rzeszów University of Technology also defines the positive impact of the impact of cooperation between enterprises and universities on the growth of innovation.

\section{Discussion}

The relationship that exists between science and business is extremely important to the economic development of the country. How technical universities use the resources of business and vice versa will lead to the development or weakening of the economy. Today, in the era of digitalization of the economy, it is important to establish relationships between universities and businesses so that together we can create new innovative solutions and reduce the barriers that have arisen. A better understanding of networking opportunities helps to create new forms of relationships. In particular, it is important for both communities to focus on improving social and networking skills, and also that's why this area is very important to get to know each other better.

\section{Summary}

Research carried out on a group of representatives of technical universities in Poland confirmed the key role of creating conditions for cooperation between polytechnic universities and small and medium-sized enterprises. This study made it possible to identify a number of factors supporting and limiting cooperation between science and business. The technical universities subject to the study have enormous scientific, expert, and premises facilities, which is an extraordinary asset and a factor facilitating and improving cooperation. The advantages of universities of technology that entrepreneurs cannot afford increase not only the interest in starting cooperation but above all gives greater opportunities for cooperation, creating better educators with up-to-date knowledge of business and economic life. The study was limited to a sample of $30 \%$ of technical universities in Poland, which means that a part of economic reality was verified. Future research direction will focus on understanding small and medium-sized enterprises and their motives and barriers in the area of undertaking cooperation with the university of technology to better understand both science and business environments.

There are many challenges ahead of the analyzed environments.

In order to better strengthen cooperation, universities and enterprises should continue their initiatives to undertake this cooperation. This is extremely important for creating the right conditions for mutual support. Particular attention should be paid to taking actions in the future to eliminate or minimize the bureaucracy associated with undertaking cooperation. Taking joint actions will also contribute to changes at the university towards the better adaptation of students to the realities of work in enterprises and the economy because a frequent problem is the clash of the theory obtained during studies with the reality on the labor market. Focusing on an even better understanding of mutual needs, increasing tolerance, and mutual trust will undoubtedly contribute to a better understanding of cooperation between entities such as science and business. 
References:

[1]. Adamik A., Powiazania wspótpracy międzyorganizacyjnej $w$ zarzadzaniu wspótczesnymi przedsiębiorstwami [w:] W. Kowalczewski, W. Matwiejczuk, (red.) Zarządzanie organizacjami w teorii i praktyce, Difin, Warszawa 2008, pp. 60-73

[2]. Grabowska M., Wspótdziałanie przedsiębiorstw $w$ perspektywie sieciowej, „Organizacja i Zarządzanie. Zeszyty Naukowe Politechniki Śląskiej”, nr.76, 2014, pp. 51-61.

[3]. Hazem ALI ,Yunhong HAO ,Chen AIJUAN, (2020) Innovation Capabilities and Small and Medium Enterprises' Performance: An Exploratory Study, The Journal of Asian Finance, Economics and $\begin{array}{llll}\text { Business } & \text { Vol.7 } & \text { No.10 pp.959 }\end{array}$ DOI https://doi.org/10.13106/jafeb.2020.vol7.no 10.959 , ISSN : 2288-4645.

[4]. Marszałek A., Relacje między światem nauki i przemysłu, „e-mentor” 2014, nr 56(4), s. 44-53, https://doi. org/10.15219/em56.1123

[5]. Meissner D. (2015) Public-Private Partnership Models for Science, Technology, and Innovation Cooperation, Springer, pp.1

[6]. Micek G., Piziak B., Wpływ bliskości międzyorganizacyjnej na rozwój usług IT w Krakowie i na Górnym Śląsku, "Studia Ekonomiczne. Zeszyty Naukowe Uniwersytetu Ekonomicznego w Katowicach", nr 320, 2017 pp. 107-128.

[7]. Mueller-Using S., Urban W.,Wedemeier J., (2020) Internationalization of SMEs in the Baltic Sea

[8]. N.R. dos Santos a,b, C. Figueiredoc, d, L. Pais e,f, (2020) Development and validation of the organisational cooperation questionnaire, European Review of Applied Psychology Volume 70, Issue 4, October 2020, 100555, pp.1.

[9]. Region: Barriers of cross-national collaboration considering regional innovation strategies for smart specialization, Wiley Periodicals LLC, p.2. https://onlinelibrary.wiley.com/doi/epdf/10. 1111/grow.12439

[10]. Roper S. Love J.H, Knowledge context, learning and innovation: an integrating framework, "Industry and Innovation", vol. 25(4), 2018, pp. 339-364.

[11]. Sandberg, S. (2012). Internationalization processes of small and medium- sized enterprises: Entering and taking off from emerging markets (Doctoral Dissertation). Retrieved from http://www.divaportal.org/smash/record.jsf?pid=diva2\%3A $504939 \&$ dswid $=-2578$.

\section{Creative Commons Attribution License 4.0 (Attribution 4.0 International, CC BY 4.0)}

This article is published under the terms of the Creative Commons Attribution License 4.0

https://creativecommons.org/licenses/by/4.0/deed.en US 